\title{
Amylography of Plantain, Cassava, and Tanier Flours ${ }^{1}$
}

\author{
Edelmiro J. Rodríguez-Sosa, José R. Cruz-Cay, and Isabel B. de Caloni ${ }^{2}$
}

\begin{abstract}
The pasting properties of plantain (Musa acuminata $\times$ balbisiana AAB), cassava (Manihot esculenta, Crantz), and tanier (Xanthosoma spp.) flours and of various mixtures prepared thereof were studied with the Brabender Amylograph-Viscograph. The flour mixtures were prepared with the following percentages: $50-25-25,60-20-20,75-15-10$, and $75-10-15$, each flour as the main one in at least one mixture. The slurries used in the amylography of the individual flours were prepared by using $27.5,35$, and $40 \mathrm{~g}$ of flour; and those of the flour mixtures with $35 \mathrm{~g}$ of the mixtures. These were mixed with $450 \mathrm{ml}$ distilled water. Starches of individual flours as well as the mixtures of flours were not fragile and were relatively stable. Different from flours where cassava and tanier were used as the main flour, when plantain was used as the main one, pasting measurements increased with the increase in plantain flour percentage. The reaggregation tendency and pasting measurements were higher in flours when plantain was used as the main flour.
\end{abstract}

\section{INTRODUCTION}

Vegetables containing starch are extensively used as staple foods in many tropical countries the world over. Among these, plantain (Musa acuminata $\times$ balbisiana $\mathrm{AAB}$ ), cassava (Manihot esculenta, Crantz), and tanier (Xanthosoma spp.) are extensively cultivated. Starch is the most important constituent of all these staples, but aside from cassava, comparatively little is known of their physical and chemical properties and their influence on processed products.

Starch provides many desirable as well as undesirable properties to foods. Hall and Fryer (3) suggested that cell rupture results in the release of the free starch from the plant cell with a resultant poor consistency.

Various methods have been developed to evaluate the rheological properties of starchy processed products. Smith and Davis (12) developed a method for measuring consistency or pastiness in mashed potatoes with a Shear Press. Cooley et al. (1) described a method for measuring the viscosity of potato granules with a Brookfield viscosimeter. However, the Amylograph-Viscograph ${ }^{3}$ has been the instrument used most exten-

${ }^{1}$ Manuscript submitted to Editorial Board August 4, 1982.

${ }^{2}$ Food Technologist, Associate Food Technologist, and Associate Food Technologist respectively, Food Technology Laboratory, Agricultural Experiment Station, Mayagüez Campus, University of Puerto Rico, Río Piedras, P.R.

${ }^{3}$ Trade names in this publication are used only to provide specific information. Mention of a trade name does not constitute a warranty of equipment or materials by the Agricultural Experiment Station of the University of Puerto Rico, nor is this mention a statement of preference over other equipment or materials. 
sively to measure the changes in consistency which occur when heating, cooking and cooling starch, as well as in starchy flour slurries.

Rodriguez-Sosa et al. (8) studied the rheological characteristics of two cassava varieties and found that pasting temperature was the same for both varieties $\left(63^{\circ} \mathrm{C}\right)$, but viscosity values of their starches were different. Comparing the starches of tanier and cassava, Rodríguez-Sosa and ParsiRos (9) found that the pasting temperature of tanier starch was higher than that of cassava and that the other amylographic measurements were somewhat lower for tanier starch. They also found that tanier starch did not show peak viscosity as cassava starch did, and that tanier starch was stronger and more stable than cassava starch. Rasper (6) studied the viscosity changes of plantain, cassava and tanier (cocoyam) starches during the gelatinization process at different concentrations. He found that plantain starch was slightly less viscous than that of cassava starch and that the thinnest (lowest viscosity) paste was obtained from cooking cocoyam.

In Puerto Rico typical dishes like "pasteles," (prepared from a mixture of mainly plantain and tanier or grated cassava alone stuffed with meat and spices and wrapped in plantain leaves or in a special paper resistant to boiling water and boiled in salted water) and "alcapurrias" or "hayacas," plantain and tanier turnovers, stuffed with meat and spices are greatly appreciated. Flours of these starchy staples may be industrially prepared to facilitate the preparation of these dishes.

The research work reported herein was conducted for the purpose of obtaining information on the rheological properties of plantain, tanier and cassava flours when submitted to heating and cooling cycles.

\section{MATERIALS AND METHODS}

For peeling the plantains were soaked in water at $210^{\circ} \mathrm{F}\left(98.9^{\circ} \mathrm{C}\right)$ for $5 \mathrm{~min}$. This treatment loosens the peel from the pulp facilitating peeling by hand. Plantains were then cut into cubes of $1 / 4 \times 1 / 4 \times 1 / 4$ in $(.635 \times$ $.635 \times .635 \mathrm{~cm})$ in a cutting machine and soaked in a $1,000 \mathrm{p} / \mathrm{m}$ potassium metabisulfite solution for $3 \mathrm{~min}$. Taniers were lye-peeled following the method of Sánchez-Nieva and Hernández (10) which consists in dipping the taniers in a $15 \%$ lye solution at $93^{\circ} \mathrm{C}$ for $6.5 \mathrm{~min}$. Taniers thus peeled were dipped in a $5 \%$ citric acid solution, trimmed and then dipped for 5 min in a $1 \%$ potassium metabisulfite solution at $\mathrm{pH} 3.0$ (11). Cassavas were hand peeled, and no pretreatment was used.

Flours were prepared by the method of Rahman (5), in which the samples are placed in perforated trays of $30 \times 20 \times 2$ in $(76.2 \times 50.0 \times$ $5.08 \mathrm{~cm})$ to a depth of about $3 / 4$ in $(1.90 \mathrm{~cm})$ over the entire area of the 
tray. The trays were then placed in a cabinet dehydrator. The dry-bulb temperature was set at $200^{\circ} \mathrm{F}\left(93.3^{\circ} \mathrm{C}\right)$ and after 1 hour it was reduced to $160^{\circ} \mathrm{F}\left(71.1^{\circ} \mathrm{C}\right)$ for the remaining 5 hours of the dehydration period. The air draft was set at $0.1 \mathrm{in}(0.25 \mathrm{~cm})$. The wet bulb temperature varies between $110^{\circ} \mathrm{F}\left(43.3^{\circ} \mathrm{C}\right)$ and $130^{\circ} \mathrm{F}\left(54.4^{\circ} \mathrm{C}\right)$. The dehydrated cubes were ground in a mechanical grinder to pass through a sieve of 0.33 in $(0.84 \mathrm{~cm})$ mesh. The flour was stored in polyethylene bags.

The consistency, referred to as "viscosity," of individual flours and their mixtures was obtained with the Brabender Amylograph-Viscograph Research Model, equipped with the $700 \mathrm{~cm} / \mathrm{g}$ sensitivity cartridge. Moisture of flours were determined according to AOAC (4); and prior to the amylographic analyses, flours were placed in a vacuum oven at $60^{\circ} \mathrm{C}$ for 24 hours to eliminate excess moisture and to equalize their moisture content.

Samples for individual amylographic flour analyses were prepared by mixing 27.5, 35 and $40 \mathrm{~g}$ of flour with $450 \mathrm{ml}$ distilled water. Mixtures of plantain, cassava and tanier were prepared as follows:

$\begin{array}{ccc}\text { Plantain } & \text { Cassava } & \text { Tanier } \\ \% & \% & \% \\ 50 & 25 & 25 \\ 60 & 20 & 20 \\ 75 & 15 & 10 \\ 75 & 10 & 15 \\ 25 & 50 & 25 \\ 20 & 60 & 20 \\ 15 & 75 & 10 \\ 10 & 75 & 15 \\ 25 & 25 & 50 \\ 20 & 20 & 60 \\ 15 & 10 & 75 \\ 10 & 15 & 75\end{array}$

For the amylographic analyses of mixtures, $35 \mathrm{~g}$ flour samples were mixed with $450 \mathrm{ml}$ distilled water.

Samples of flour and distilled water were stirred for 5 min at $200 \mathrm{r} /$ min in the amylograph bowl. They were further stirred at the recording speed $(75 \mathrm{r} / \mathrm{min}$ ) for 5 additional minutes. The initial temperature for the heating cooling cycle was $30^{\circ} \mathrm{C}$. Samples were heated to $95^{\circ} \mathrm{C}$ at a constant rate of $1.5^{\circ} \mathrm{C} / \mathrm{min}$ and held at that temperature for 1 hour. Thereafter, the temperature was lowered to $50^{\circ} \mathrm{C}$ at the same rate and held there for another hour.

The data obtained in the amylographic determinations were submitted to analysis of variance and Duncan's multiple range test $(7,2)$. 


\section{RESULTS AND DISCUSSION}

Moisture content of obtained plantains, cassava, and tanier flours was $3.22 \%, 4.54 \%$, and $8.11 \%$, respectively.

Table 1 shows the results of the effect of flour weight in the amylography of slurries prepared using each flour individually. Initial viscosity was about the same for each sample weight. The highest pasting temperature was obtained with tanier flour. Pasting temperature for $35 \mathrm{~g}$ was lower than that for $27.5 \mathrm{~g}$ and for $40 \mathrm{~g}$ in all cases.

Consistency measurements increased as sample weight increased in all flours. This increase was highly significant in plantain flour and significant at the $5 \%$ level in tanier. In cassava flour there was a highly significant difference between slurries with the addition of $27.5 \mathrm{~g}$ or 40 $\mathrm{g}$, and a significant difference between samples with the addition of 27.5

TABLE 1.-Effect of plantain, cassava, and tanier flour weight on viscosity of slurries prepared from individual flours as measured with the Amylograph-Viscograph ${ }^{1}$

\begin{tabular}{|c|c|c|c|c|c|c|c|c|c|}
\hline \multirow{3}{*}{ Pasting measurements } & \multicolumn{9}{|c|}{ Flour weight (g) } \\
\hline & \multicolumn{3}{|c|}{ Plantain } & \multicolumn{3}{|c|}{ Cassava } & \multicolumn{3}{|c|}{ Tanier } \\
\hline & 27.5 & 35 & 40 & 27.5 & 35 & 40 & 27.5 & 35 & 40 \\
\hline Initial viscosity at $30^{\circ} \mathrm{C}$ & 15 & 10 & 10 & 10 & 10 & 10 & 10 & 10 & 10 \\
\hline Pasting temperature $\left({ }^{\circ} \mathrm{C}\right)$ & 71.25 & 70.5 & 73.5 & 64.5 & 63 & 67.5 & 75 & 72 & 78 \\
\hline Peak viscosity & - & - & - & - & - & 388 & - & - & - \\
\hline Viscosity at $95^{\circ} \mathrm{C}$ & 165 & 388 & 550 & 103 & 248 & 330 & 105 & 313 & 488 \\
\hline Maximum viscosity on heating & 180 & 395 & 558 & 115 & 248 & 330 & 118 & 313 & 488 \\
\hline Viscosity after 1 hour at $95^{\circ} \mathrm{C}$ & 138 & 185 & 310 & 75 & 113 & 145 & 75 & 113 & 195 \\
\hline Viscosity at $50^{\circ} \mathrm{C}$ & 160 & 288 & 530 & 83 & 145 & 213 & 83 & 143 & 308 \\
\hline Viscosity 1 hour at $50^{\circ} \mathrm{C}$ & 150 & 275 & 495 & 80 & 143 & 208 & 80 & 145 & 328 \\
\hline
\end{tabular}

${ }^{1}$ Viscosity was measured in Brabender Units (BU) and measurements were taken at 75 $\mathrm{r} / \mathrm{min}$.

g or $35 \mathrm{~g}$, but no significant difference was observed between samples with the addition of $35 \mathrm{~g}$ or $40 \mathrm{~g}$.

The samples did not show peak viscosity, except in cassava, which showed a slight one when $40 \mathrm{~g}$ of flour were used, denoting that starch of these products are relatively strong.

The stability of all flour slurries while cooking at $95^{\circ} \mathrm{C}$ decreased as flour weight increased as shown by the increase in the difference between viscosity at $95^{\circ} \mathrm{C}$ and viscosity after 1 hour at $95^{\circ} \mathrm{C}$. This decrease in viscosity is due to breakdown of the starch granules caused by overswelling and by mechanical rupture because of the constant stirring of the flour paste in the amylograph. As the differences were not too great, it can be said that, within the limits of this experiment, the flours are relatively stable on heating; this stability indicates that no special treat- 
ment is necessary to cook them. Nevertheless, stirring while cooking should be kept at a minimum to avoid the breakdown of the flour paste.

Plantain flour showed the highest power for reaggregation of its starch granules (difference between viscosity after 1 hour at $95^{\circ} \mathrm{C}$ and viscosity at $50^{\circ} \mathrm{C}$ ). This property could be important at the time of formulation since this flour in an adequate amount could stabilize the texture of the final product at the temperature at which it is commonly served on the table. The reaggregation trend increased with the increase in sample weight (significant at the $5 \%$ level in plantain and tanier, but not significant in cassava). All samples were stable while cooking at $50^{\circ} \mathrm{C}$ for 1 hour (difference between viscosity at $50^{\circ} \mathrm{C}$ and viscosity after 1 hour at $50^{\circ} \mathrm{C}$ ); this stability means that samples could stand long periods of heating.

Table 2 shows the effect of the individual flour percentages on the amylography of the mixtures of plantain, cassava and tanier flours as measured with the Amylograph-Viscograph.

Initial viscosity taken at $30^{\circ} \mathrm{C}$ and $75 \mathrm{r} / \mathrm{min}$ was about the same for all samples. Pasting temperature was lower when cassava was used as the main flour and higher when tanier was used as such. No peak viscosity was observed in any sample; thus the mixture of starches in the flours was strong.

When plantain was the main flour added, viscosity measurements increased with the increase in plantain flour percentage, but no significant difference was observed among samples using $75 \%$ plantain flour. However, there was a highly significant difference between these samples and samples using 50-25-25 and 60-20-20\% of plantain, cassava, and tanier flour, respectively. There was also a highly significant difference in viscosity measurement between 50-25-25 and 60-20-20.

When cassava and tanier were the main flours viscosity decreased with the increase in those flours. These differences were significant among cassava and tanier samples, except between samples 75-15-10 and 75-1015, when tanier was used as the main flour. Samples which used less tanier scored higher viscosity. This fact indicates that in blends tanier should be the flour used in less amount; since high amounts could render a low consistency product which desintegrates when boiled or fried. Except when tanier was used as the main flour, the same can be said of cassava flour, while the opposite occurred with plantain.

All flour mixtures reach the maximum viscosity after attaining $95^{\circ} \mathrm{C}$, thus the maximum swelling capacity was obtained after reaching that temperature. Nonetheless, differences in viscosity between these two points were very low.

Thinning down or breakdown of swelling granules was about the same 
TABLE 2.-Effect of individual flour percentages on pasting measurements of mixtures of plantain, cassava, and tanier flours as measured with an Amylograph-Viscograph ${ }^{1}$

\begin{tabular}{|c|c|c|c|c|c|c|c|c|c|c|c|c|}
\hline \multirow{2}{*}{ Pasting measurements } & \multicolumn{4}{|c|}{ Plantain-cassava-tanier (\%) } & \multicolumn{4}{|c|}{ Cassava-plantain-tanier (\%) } & \multicolumn{4}{|c|}{ Tanier-plaintain-cassava (\%) } \\
\hline & $50-25-25$ & $60-20-20$ & $75-15-10$ & $75-10-15$ & $50-25-25$ & $60-20-20$ & $75-15-10$ & $75-10-15$ & $50-25-25$ & $60-20-20$ & $75-15-10$ & $\begin{array}{c}75-10 \\
15\end{array}$ \\
\hline Initial viscosity at $30^{\circ} \mathrm{C}$ & 5 & 5 & 10 & 10 & 10 & 10 & 10 & 10 & 10 & 10 & 10 & 10 \\
\hline Pasting temperature & 76.5 & 76.5 & 73.5 & 75 & 73.5 & 72 & 69.75 & 70.5 & 76.5 & 76.5 & 78 & 76.5 \\
\hline Viscosity at $95^{\circ} \mathrm{C}$ & 275 & 290 & 320 & 290 & 243 & 230 & 215 & 200 & 248 & 250 & 223 & 233 \\
\hline $\begin{array}{l}\text { Maximum viscosity on heat- } \\
\text { ing }\end{array}$ & 290 & 305 & 328 & 315 & 253 & 238 & 225 & 215 & 260 & 258 & 238 & 238 \\
\hline $\begin{array}{l}\text { Viscosity after } 1 \text { hour at } 95^{\circ} \\
\text { C }\end{array}$ & 175 & 183 & 203 & 200 & 143 & 130 & 130 & 130 & 143 & 140 & 130 & 130 \\
\hline Viscosity at $50^{\circ} \mathrm{C}$ & 278 & 298 & 328 & 310 & 215 & 198 & 188 & 178 & 220 & 208 & 195 & 200 \\
\hline $\begin{array}{l}\text { Viscosity after } 1 \text { hour at } 50^{\circ} \\
\quad \text { C }\end{array}$ & 265 & 278 & 310 & 293 & 208 & 185 & 178 & 168 & 215 & 203 & 195 & 195 \\
\hline
\end{tabular}

${ }^{1}$ Viscosity was measured in Brabender Units and measurements were taken at $75 \mathrm{r} / \mathrm{min}$. 
for all mixtures, but the reaggregation tendency was higher in samples in which plaintain was the main flour. This reaggregation indicates that those samples will have a better or higher consistency when they get cold after preparation. Maximum reaggregation was observed in the mixture 75-15-10, followed by the mixture 75-10-15. All mixtures showed good stability while cooking at $50^{\circ} \mathrm{C}$.

When the three flours were compared within the same level of addition it was found that viscosity measurements were always significantly higher (1\% level) in plaintain flour at all levels, and that there was not a significant difference between cassava and tanier mixtures, although cassava showed the lowest viscosity measurements.

\section{RESUMEN}

Se estudiaron las características de pastosidad en harinas de plátano (Musa acuminate $\times$ balbisiana AAB), yuca (Manihot esculenta, Crantz) y yautía (Xanthosoma spp.) y varias mezclas preparadas de éstas utilizando el amiloviscógrafo Brabender. Las mezclas acuosas para usarse en la amilografia de las harinas individuales se prepararon con 27.5, 32 y $40 \mathrm{~g}$ de harina y $450 \mathrm{ml}$ de agua destilada. Las mezclas de harinas se prepararon en porcentajes de 50-25-25, 60-20-20, 75-15-10 y 75-10-15 utilizando una de las tres harinas como la principal en una ocasión, por lo menos. Las mezclas acuosas de las mezclas de harinas se prepararon con $35 \mathrm{~g}$ y 450 $\mathrm{ml}$ de agua destilada.

El examen individual del almidón de las harinas demostró que no es frágil, sino relativamente estable. El almidón de la harina de plátano mostró el mayor grado de reagregación, reflejándose así mismo en la mezcla con la harina de plátano como el componente principal.

Contrario a las mezclas en las que se usó la yuca o la yautía como las harinas principales, en las de plátano las medidas de pastosidad aumentaron con el aumento en el porcentaje de esta harina.

\section{LITERATURE CITED}

1. Cooley, A. M., Severson, D. E., Peightal, D. E. and Wagner, J. R., 1954. Studies on dehydrated potato granules, Food Technol. 8: 263-69.

2. Duncan, D. B., 1955. Multiple range and multiple F tests, Biometrics 2: 1-42.

3. Hall, R. C. and Fryer, H. C., 1953. Consistency evaluation of dehydrated potato granules and directions for microscopic rupture count procedure, Food Technol. 7 (9): 373-6.

4. Official Methods of Analysis of the Association of Official Analytical Chemists, 1975, 12th ed, Washington, D. C.

5. Rahman, A. R., 1963. Economical method for the production of flour from green platains, J. Agric. Univ. P.R. 47 (1): 1-10.

6. Rasper, V., 1969. Investigation of starches from major starch crops grown in Ghana, J. Sci. Food, Agric. 20 (3): 165-71.

7. Robinson, P., 1959. Test of significance, Bull. Stat, Res. Ser., Canada Dep. Agric. 
8. Rodríguez-Sosa, E. J., Parsi-Ros, O. and Gonzáles, M. A., 1976. Composition of cassava (Manihot esculenta, Crantz) and the rheological characteristics of its starch, J. Agric. Univ. P. R. 60 (1): 93.8.

9. - and 1981. Proximate composition of tanier (Xanthosoma spp) and cassava (Manihot escuenta, Crantz) and the rheological properties of their starches, ScienceCiencia, Boletín Cientifico del Sur 8 (1): 3-8.

10. Sánchez-Nieva, F. and Hernández, I. 1977. Lye peeling of taniers (Xanthosoma spp.) J. Agric. Univ. P. R. 61 (3): 345-53,

11. _ 1977. Control of browning in lye-peeled taniers, J. Agric. Univ. P. R. 61 (4): 489500.

12. Smith, O. and Davis, C. O., 1967. Potato Quality XV. Improving texture and measuring textural changes in potato flour, Am. Potato J. 40:67-80. 